DOI: 10.17951/lrp.2020.39.2.243-257

\author{
DANUTA Wosik-KaWALA \\ Uniwersytet Marii Curie-Skłodowskiej \\ ORCID - 0000-0003-2846-7203
}

\title{
SAMOOCENA MŁODZIEŻY STOJĄCEJ \\ U PROGU DALSZEGO KSZTAŁCENIA LUB TRANZYCJI NA RYNEK PRACY - NA PRZYKŁADZIE UCZNIÓW LUBELSKICH SZKÓŁ PONADPODSTAWOWYCH
}

\begin{abstract}
Streszczenie: Samoocena jest jednym z czynników warunkujących funkcjonowanie człowieka w wielu obszarach życia, zarówno osobistego, jak i zawodowego. Wpływa na podejmowane przez człowieka decyzje, w tym na jego karierę zawodową. Celem przeprowadzonych badań była próba określenia samooceny młodzieży stojącej u progu dalszego kształcenia lub tranzycji na rynek pracy. Próbę badawczą stanowiło 299 uczniów lubelskich szkół, w tym: zasadniczej szkoły zawodowej, technikum i liceum ogólnokształcącego. W badaniu zastosowano Skalę Samooceny SES - the Rosenberg Self-Esteem Scale (SES) autorstwa Morrisa Rosenberga. Analiza danych ukazała, że uczniowie z różnych typów szkół, stojący u progu dorosłości nie różnią się istotnie statystycznie ze względu na posiadaną samoocenę. Różnic nie odnotowano także, uwzględniając płeć badanych osób. Niepokojący jednak okazał się fakt, że aż co czwarty badany posiadał niski, niekorzystny poziom samooceny. W przypadku tych uczniów należałoby podjąć działania mające na celu podniesienie ich samooceny.
\end{abstract}

Słowa kluczowe: adolescencja, samoocena, uczniowie, młodzież

\section{WPROWADZENIE}

Kończąc szkołę ponadpodstawową, młodzi ludzie stają przed podjęciem wielu ważnych decyzji, w tym dotyczących własnej przyszłości zawodowej, a co się z tym wiąże - dotyczących podjęcia pracy zawodowej lub dalszego kształcenia, m.in. w szkołach policealnych, pomaturalnych czy też na studiach. Młodzież w tym okresie życia, zwanym późną adolescencją, wiekiem młodzieńczym bądź okresem dorastania, charakteryzuje się przeżywaniem wielu problemów, a najważniejsze 
z nich koncentrują się na dorastaniu psychospołecznym (zob. Obuchowska 1983, 1996, 2010; Brzezińska 2003; Przetacznik-Gierowska, Tyszkowa 2009). Zachodzące w tym czasie zmiany rozwojowe zmierzają do formowania własnej tożsamości oraz autonomii wobec rodziców. Poszukiwaniu własnej tożsamości niejednokrotnie towarzyszy kryzys tożsamości. W fazie kryzysu poczucia tożsamości młody człowiek zmaga się z problemami dotyczącymi samookreślenia, stara się odnaleźć odpowiedzi na nurtujące go pytania, dotyczące m.in. tego, kim jest, kim może być, jak wygląda w oczach innych i mimo że często nie zna na nie odpowiedzi, to ma świadomość, że „chce być kimś innym, niż był dotychczas” (Musiał 2007, s. 84). W tym okresie życia główne zadania rozwojowe odnoszą się do wyboru przez młodzież zawodu i pracy (kariery zawodowej), autonomii w stosunku do rodziców oraz zinternalizowanej moralności (Brzezińska 2003). Zdaniem Erika H. Eriksona (1968, za: Obuchowska 2010, s. 189) kryzys tożsamości jest naturalnym doświadczeniem w tym okresie rozwojowym, a jego pomyślne zakończenie umożliwia młodemu człowiekowi wejście $\mathrm{w}$ dorosłość jako osobie wewnętrznie silnej i niezależnej. Z tej krótkiej charakterystyki wynika, że jest to czas dynamicznych zmian, z którymi młodzi ludzie muszą się zmierzyć. To także czas, w którym podejmowane decyzje $\mathrm{z}$ jednej strony zależą od rodzaju posiadanej samooceny, z drugiej zaś skutki tych decyzji mają wpływ na jej rodzaj i poziom.

W literaturze psychologiczno-pedagogicznej można odnaleźć wiele określeń współwystępujących wraz z pojęciem samooceny. Należą do nich m.in. poczucie własnej wartości, obraz siebie, samowiedza, system wiedzy o własnej osobie, świadomość siebie. Sytuacja taka stanowi pewną niejasność terminologiczną, gdyż zazwyczaj relacje między tymi obszarami nie są jasno określane. Definiowanie terminu „samoocena” również doczekało się wielu podejść i interpretacji (por. Wosik-Kawala 2007, s. 15). W polskiej literaturze psychologicznej można wyróżnić kilka teorii wyjaśniających istotę samooceny. Bogdan Wojciszke wyjaśnia, że samoocena ma „dwoistą naturę procesu i cechy”. Jako proces jest „bieżącym wartościowaniem własnej osoby ukierunkowanym na cel, jaki stanowi pozytywny wniosek na własny temat" (Wojciszke 2015, s. 175), jako cecha zaś oznacza „trwałą skłonność do wartościowania samego siebie w pozytywny lub negatywny sposób" (Wojciszke 2015, s. 176). Jest to zatem postawa wobec samego siebie, mogąca przybrać postać deklaratywną lub ukrytą. Samoocena deklaratywna to świadome przekonanie na temat ogólnej wartości własnej osoby, mierzone za pomocą słownych deklaracji. Natomiast ukryta wynika „Z wartościowości obiektów skojarzonych z ja" (Wojciszke 2015, s. 176). Samoocena deklaratywna cechuje się znaczną stabilnością, ukryta zaś nie jest stała w czasie (Wojciszke 2015, s. 176).

Również Wilhelmina Wosińska przyjmuje rozumienie samooceny jako postawy wobec samego siebie. Autorka uważa, że samoocena jest „globalnym oszacowaniem 
własnej wartości lub - innymi słowy - postawą wobec samego siebie" (Wosińska 2004, s. 67). Postawa ta to „wypadkowa schematów Ja obejmujących różne atrybuty, takie jak wygląd fizyczny, inteligencja, status ekonomiczny, uczciwość i tym podobne" (Wosińska 2004, s. 67). Natomiast Leon Niebrzydowski stwierdza, że samoocena jest elementem systemu wiedzy człowieka o sobie samym i stanowi trzon obrazu własnej osoby. To „zespół sądów i opinii, które jednostka odnosi do swojej osoby, a w szczególności do swojego wyglądu, uzdolnień, osiągnięć i możliwości życiowych" (Niebrzydowski 1974, s. 359). Oszacowanie wartości samego siebie jako osoby dobrej, kompetentnej, przyzwoitej stanowi podstawę definiowania samooceny przez Elliota Aronsona, Timothy'ego D. Wilsona i Robin M. Akert (Aronson i in. 1997, s. 21). Analiza licznych podejść w definiowaniu samooceny dokonana przez Janusza Kirenkę (2002, s. 128) umożliwiła autorowi wypracowanie stanowiska traktującego samoocenę jako postawę wobec samego siebie, swoich cech, możliwości, zdolności i wad, stanowiącą emocjonalny komponent obrazu własnej osoby, czyli zespół różnorodnych sądów i opinii, które jednostka odnosi do siebie, a dotyczących fizycznych, psychicznych i społecznych właściwości danego człowieka. Taki sposób rozumienia samooceny jest zbliżony do poglądów Morrisa Rosenberga, według którego samoocena to subiektywny konstrukt, oparty na percepcji i ocenie własnej osoby. Jest więc świadomą postawą wobec własnego Ja, zależną zarówno od emocji związanych z własnym Ja, jak i poznawczych sądów na swój temat (por. Dzwonkowska, Lachowicz-Tabaczek, Łaguna 2008, s. 11-12). Analiza różnych ujęć definicyjnych pojęcia samooceny umożliwia wyodrębnienie dwóch głównych podejść. W przypadku definicji z grupy pierwszej odnosi się do mechanizmu poznawczego, nacisk położony jest tu na percepcję siebie, wiedzę o własnym Ja, na którą składają się przekonania i pojęcia jednostki na własny temat. Element poznawczy to posiadane przez jednostkę świadome wyobrażenia oraz wiedza o swoich fizycznych właściwościach, to pojęcie o sobie samym, o własnych cechach, zdolnościach, swojej roli i możliwościach. Drugie podejście traktuje samoocenę jako system poznawczo-oceniający, co wiąże się z posiadaniem przez jednostkę szeroko rozumianej wiedzy o sobie oraz krytycznym stosunkiem do siebie przejawiającym się w samoocenie (Wosik-Kawala 2007, s. 16-17). W prezentowanych badaniach przyjęłam rozumienie samooceny zgodnie z koncepcją Morrisa Rosenberga (por. Dzwonkowska, Lachowicz-Tabaczek, Łaguna 2008, s. 11-12). Warto w tym miejscu zaznaczyć, że istnieje wiele kryteriów określania samooceny, można zatem mówić o samoocenie globalnej i samoocenach cząstkowych, oba rodzaje mogą być rozpatrywane w następujących wymiarach: jako samoocena wysoka - niska, stabilna - niestabilna, adekwatna - nieadekwatna (zawyżona bądź zaniżona), pozytywna - negatywna, pewna - zagrożona (por. Tyszkowa 1972; Brzezińska 1973; Niebrzydowski 1976, 1989; Reykowski 1982; Kulas 1986; Kulig 1988). 
Stosunek człowieka do samego siebie determinuje jego relacje z innymi ludźmi, podejmowane zadania, odnoszone sukcesy bądź poniesione porażki. Posiadany przez niego poziom samooceny to jeden $\mathrm{z}$ ważnych czynników decydujących o wyznaczanych celach życiowych i ocenach słuszności podejmowanych działan. $\mathrm{W}$ momencie ustalania ścieżki edukacyjno-zawodowej samoocena jest jednym z determinantów warunkujących wybór szkoły i zawodu. Stąd też osoby z zawyżoną samooceną najprawdopodobniej przeżyją wiele stresu i frustracji spowodowanych najczęściej nieadekwatnym do swoich możliwości wyborem kariery edukacyjno-zawodowej, w przypadku zaś osób o niskiej samoocenie istnieje duże ryzyko, że nie wykorzystają one w pełni posiadanego potencjału i również nie będą zadowolone ze swojego wyboru (Wosik-Kawala, Sarzyńska-Mazurek 2017, s. 61). Osoba o niskim poziomie samooceny na ogół nie docenia swoich sukcesów, nie wierzy we własne możliwości, zazwyczaj niekorzystnie wypowiada się na swój temat oraz na temat innych. Osoby takie wyolbrzymiają trudności, którym dość łatwo się poddają, rezygnują z wykonywania zadań, nie wykorzystują pojawiających się szans na osiągnięcie sukcesów. W sytuacji gdy człowiek przecenia swoje możliwości, jest przekonany o własnej wyjątkowości, wówczas również dokonuje niewłaściwych wyborów, zazwyczaj są one zbyt trudne, nieadekwatne do jego możliwości. Zachowania takich osób są nieodpowiednie, gdyż nie realizują powziętych zobowiązań, a w konsekwencji ponoszą wiele porażek. Z perspektywy dokonywanych wyborów ważne jest, by człowiek posiadał adekwatną samoocenę, gdyż wtedy na ogół „stawia przed sobą realistyczne cele, jest przekonany o słuszności dokonywanych wyborów życiowych, potrafi też spojrzeć na siebie z dystansu, zająć elastyczne stanowisko" (Grabowiec 2011, s. 74). Jednocześnie osoby takie są wytrwałe w wykonywaniu zadań, mają mniej problemów emocjonalnych, ich zachowanie jest dojrzałe i konstruktywne, potrafią radzić sobie z porażką (Grabowiec 2011, s. 75). Samoocena to zatem czynnik mający znaczenie przy podejmowaniu przez młodzież decyzji odnośnie do ich kariery zawodowej. Uczeń, wybierając ścieżkę dotyczącą jego kariery zawodowej, powinien umieć wskazać te obszary, w których czuje się dobrze, znać swój potencjał (zainteresowania, cechy osobowości) oraz posiadać wiedzę o rynku pracy (Podoska-Filipowicz 2003). Decyzje młodzieży dotyczące ich przyszłości edukacyjno-zawodowej dla wielu z nich są bardzo trudne i złożone. Ich podjęcie wymaga od młodzieży znajomości samego siebie, umiejętności odpowiedzenia na pytania: „kim jestem?” oraz „kim mogę być?", co wiąże się z samopoznaniem i samookreśleniem. Bez odpowiedzi na te, jak wydawałoby się, proste pytania dotyczące własnej osoby, podjęcie przez młodzież samodzielnej decyzji odnośnie do kariery zawodowej wydaje się niemożliwe (por. Czerwińska-Jasiewicz 2011, s. 207). 


\section{BADANIA WŁASNE}

Celem prowadzonych badań empirycznych jest próba określenia samooceny młodzieży stojącej u progu dalszego kształcenia lub tranzycji na rynek pracy. Zagadnienie to jest rozpatrywane w kontekście typu szkoły, do której uczęszczają badani uczniowie, czyli zasadniczej szkoły zawodowej, technikum i liceum ogólnokształcącego. W ten sposób określony cel badań upoważnia do sformułowania problemu badawczego zawierającego się w pytaniu: jaki jest poziom samooceny młodzieży stojącej u progu dalszego kształcenia lub tranzycji na rynek pracy? W kontekście tak określonego problemu badawczego posłużono się następującymi pytaniami szczegółowymi:

- Jaki jest poziom samooceny uczniów zasadniczej szkoły zawodowej, technikum i liceum?

- Czy istnieją - a jeśli tak, to jakie - różnice w zakresie samooceny pomiędzy uczniami zasadniczej szkoły zawodowej, technikum i liceum?

- Jaki jest poziom samooceny dziewcząt i chłopców ze szkół ponadgimnazjalnych?

- Czy istnieją - a jeśli tak, to jakie - różnice w zakresie samooceny pomiędzy badanymi dziewczętami a chłopcami?

Sformułowane pytania mają charakter diagnostyczny, dlatego też zgodnie z zasadami obowiązującymi w metodologii badań nie wymagają wysuwania hipotez roboczych. W celu uzyskania odpowiedzi na postawione problemy badawcze posłużono się metodą sondażu diagnostycznego z zastosowaniem techniki ankietowania. Natomiast wybór narzędzia badawczego był spowodowany przyjęciem rozumienia samooceny zgodnie z koncepcją Rosenberga, wiekiem osób badanych - tak, by właściwości psychometryczne narzędzia odpowiadały grupie wiekowej badanych oraz możliwością przeprowadzenia badań zbiorowych. Dlatego też uwzględniając powyższe warunki, w badaniach zastosowano Skalę Samooceny SES autorstwa Morrisa Rosenberga (the Rosenberg Self-Esteem Scale). Samoocena mierzona za pomocą tego narzędzia jest rozumiana jako przekonanie o własnej wartości, ujawniane w samoopisie i traktowane jako stosunkowo stała właściwość danej osoby; to zatem pozytywna lub negatywna postawa wobec Ja. Odzwierciedla aktualnie doświadczany przez jednostkę poziom aprobaty i akceptacji społecznej, jest podatna na zmiany pod wpływem nastroju, informacji zwrotnej, poziomu akceptacji społecznej, rodzaju dokonywanej autoprezentacji, wysiłku włożonego w zadanie oraz aspektu dokonywanej oceny (Dzwonkowska i in. 2008, s. 15-16). Narzędzie to mierzy samoocenę deklaratywną, rozumianą jako „świadome przekonanie na temat ogólnej wartości własnej osoby mierzone za pomocą słownych deklaracji [...], cechuje się dużą stabilnością czasową i zgodnością wewnętrzną" 
(Wojciszke 2015, s. 176). Obecnie to jedno z najpopularniejszych narzędzi do określenia samooceny. Badania walidacyjne pokazały, że polska wersja SES jest rzetelnym narzędziem (rzetelność polskiej wersji kwestionariusza oszacowana za pomocą współczynnika Cronbacha wahała się od 0,81 do 0,83 ) o potwierdzonej trafności teoretycznej.

Badania odbyły się w 2018 roku, objęto nimi 299 uczniów z ostatnich klas szkoły zawodowej, technikum i liceum ogólnokształcącego z terenu miasta Lublin. Badania przeprowadzono w sześciu szkołach (2 licea, 2 technika i 2 zasadnicze szkoły zawodowe) $)^{1}$. W badaniu uczestniczyło 98 uczniów technikum $(32,78 \%$ ogółu badanych), 99 uczniów z zasadniczej szkoły zawodowej (33,11\% ogółu badanych) i 102 uczniów z liceum ogólnokształcącego (34,11\% ogółu badanych). Ogółem przebadano 151 dziewcząt (50,50\% badanych) i 148 chłopców $(49,50 \%$ badanych). W liceum badaniem objęto 43 chłopców i 59 dziewcząt, w technikum 47 chłopców i 51 dziewcząt, w zasadniczej szkole zawodowej zaś 58 chłopców i 41 dziewcząt. Najmłodsi badani byli w wieku 18 lat (40 osób), a najstarsi - 21 lat (5 osób), średni wiek badanych uczniów wyniósł 19 lat i 2 miesiące. W odniesieniu do poszczególnych typów szkół wiek uczniów wyniósł: w zasadniczej szkole zawodowej 18 lat i 8 miesięcy, w technikum 19 lat i 7 miesięcy, a w liceum 19 lat i 1 miesiąc. W badaniach zastosowano losowo-celowy dobór grupy badawczej. Dobór losowy dotyczył szkół, w których przeprowadzono badania, celowy zaś uwzględniał zarówno typ szkoły - szkoły ponadgimnazjalne, jak i wiek uczniów: osoby kończące naukę na tym szczeblu edukacyjnym.

\section{WYNIKI BADAŃ}

Podobieństwa i różnice w zakresie samooceny uczniów z zasadniczej szkoły zawodowej, technikum i liceum ogólnokształcącego określono na podstawie jednoczynnikowej analizy wariancji ANOVA, która umożliwia analizę układów z jednym predyktorem jakościowym.

${ }^{1}$ Od roku szkolnego 2017/2018 w Polsce rozpoczęto wygaszanie gimnazjum, a od 31 sierpnia 2019 roku w konsekwencji wprowadzonej reformy systemu oświaty z 2017 roku gimnazja zostały zlikwidowane. Wprowadzono natomiast 8-klasową szkołę podstawową oraz szkoły ponadpodstawowe: 4-letnie liceum ogólnokształcące, 5-letnie technikum oraz 3-letnią szkołę branżową I stopnia i 2-letnią II stopnia. Prezentowane w niniejszej publikacji badania przeprowadzono w 2018 roku wśród uczniów nieobjętych jeszcze reformą oświaty z 2017 roku. 
Tabela 1. Samoocena badanych uczniów z uwzględnieniem szkoły, do której uczęszczają

\begin{tabular}{|l|c|c|c|c|}
\hline \multirow{2}{*}{\multicolumn{1}{|c|}{ Szkoła }} & \multicolumn{3}{|c|}{ Samoocena } \\
\cline { 2 - 3 } & $\bar{\chi}$ & $\hat{\boldsymbol{S}}$ & $\boldsymbol{F}$ & $\boldsymbol{p}$ \\
\cline { 2 - 3 } & 28,82 & 3,26 & & \\
\hline Zawodowa & 28,09 & 3,50 & \multirow{2}{*}{0,53} & \multirow{2}{*}{0,59} \\
\hline Technikum & 28,88 & 5,21 & & \\
\hline Liceum & 28,76 & 4,72 & & \\
\hline Razem & & & & \\
\hline
\end{tabular}

Źródło: badania własne.

Porównując wyniki badań w zakresie samooceny osiągnięte przez uczniów szkoły zawodowej, technikum i liceum, należy stwierdzić, że uzyskany średni wynik w zakresie samooceny w każdej grupie jest bardzo podobny, a różnica między średnimi wynikami wynosi jedynie 0,06 między średnim wynikiem uzyskanym przez uczniów z liceum i szkoły zawodowej, 0,73 między średnim wynikiem uzyskanym przez uczniów ze szkoły zawodowej i technikum oraz 0,79 między średnim wynikiem uzyskanym przez uczniów z liceum i technikum. W zakresie tej zmiennej nie występują między wyróżnionymi grupami różnice istotne statystycznie $(F=0,53 ; p<0,59)$. W związku z tym, że analiza wariancji nie wykazała różnic istotnych statystycznie pomiędzy porównywanymi grupami, nie przeprowadzono dalszych testów. Można więc przyjąć, że badani uczniowie - bez względu na to, do której szkoły uczęszczają - posiadają zbliżony poziom samooceny. Należy również zauważyć, że uzyskana średnia we wszystkich badanych grupach plasuje się na poziomie 5 i 6 stena, co wskazuje na przeciętny wynik w zakresie samooceny badanych uczniów. Uzyskane wyniki zilustrowano na wykresie 1.

Sytuacja ukazana na wykresie 1 wskazuje nieznaczne różnice w zakresie samooceny między uczniami z zasadniczej szkoły zawodowej, technikum i liceum. Na podstawie informacji zawartych na wykresie można stwierdzić, że uczniowie z zasadniczej szkoły zawodowej i liceum osiągnęli bardzo zbliżone średnie wyniki w zakresie samooceny, uczniowie technikum zaś w zakresie analizowanej zmiennej osiągnęli wyniki nieco niższe. Należy zauważyć, że wśród uczniów technikum znalazły się osoby, które uzyskały najniższe wyniki w zakresie samooceny wśród wszystkich badanych uczniów. Co ciekawe, najwyższe wyniki w zakresie tej zmiennej uzyskane przez uczniów technikum były znacznie niższe niż u uczniów z najwyższymi wynikami z liceum i szkoły zawodowej. 


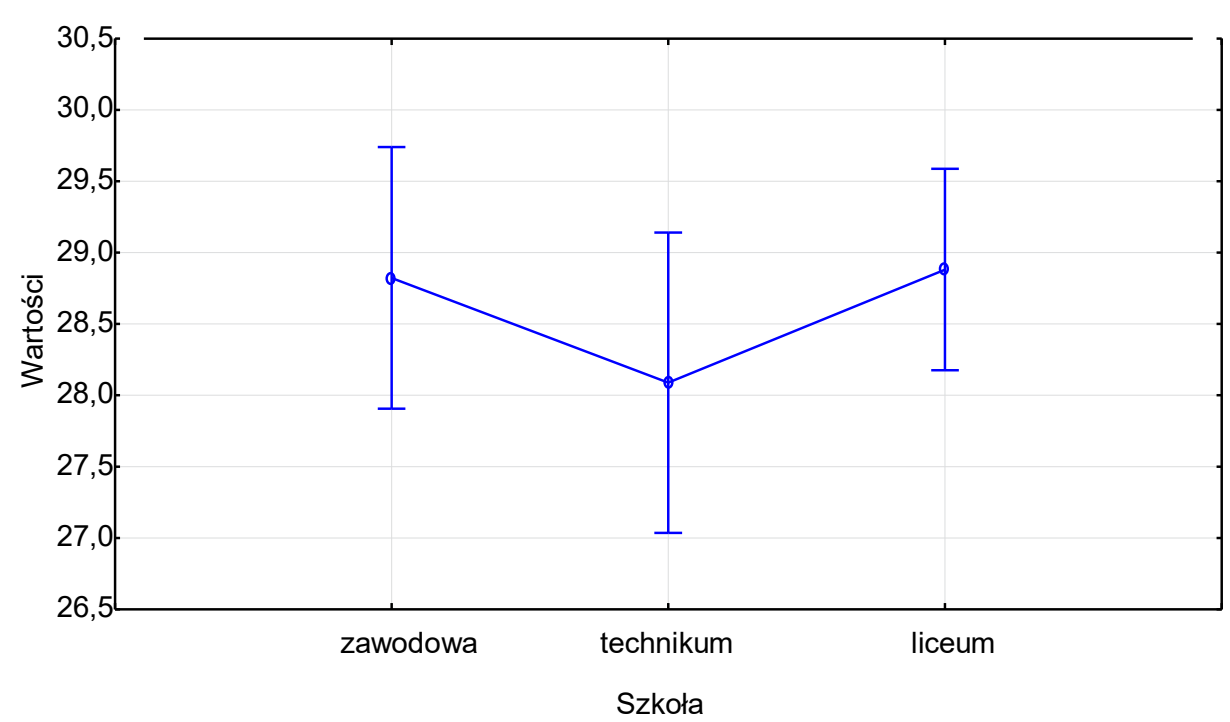

Wykres 1. Samoocena badanych uczniów z uwzględnieniem szkoły, do której uczęszczają

Chcąc poznać, jaki poziom samooceny posiadają uczniowie z poszczególnych typów szkół, obliczono dla każdej grupy oddzielnie, ilu uczniów z danej szkoły reprezentuje poszczególny poziom samooceny. Uzyskane wyniki badań zaprezentowano w tabeli 2.

Tabela 2. Poziom samooceny badanych uczniów z uwzględnieniem szkoły, do której uczęszczają

\begin{tabular}{|c|c|c|c|c|c|c|c|c|c|c|c|c|}
\hline \multirow{3}{*}{ Szkoła } & \multicolumn{10}{|c|}{ SAMOOCENA } & \multirow{2}{*}{\multicolumn{2}{|c|}{ Razem }} \\
\hline & \multicolumn{2}{|c|}{ Bardzo niski } & \multicolumn{2}{|c|}{ Niski } & \multicolumn{2}{|c|}{ Przeciętny } & \multicolumn{2}{|c|}{ Wysoki } & \multicolumn{2}{|c|}{$\begin{array}{l}\text { Bardzo } \\
\text { wysoki }\end{array}$} & & \\
\hline & $N$ & $\%$ & $N$ & $\%$ & $N$ & $\%$ & $N$ & $\%$ & $N$ & $\%$ & $N$ & $\%$ \\
\hline Zawodowa & 2 & 2,02 & 21 & 21,21 & 61 & 61,62 & 13 & 13,13 & 2 & 2,02 & 99 & 100 \\
\hline Technikum & 7 & 7,14 & 15 & 15,31 & 57 & 58,16 & 19 & 19,39 & 0 & 0 & 98 & 100 \\
\hline Liceum & 6 & 5,88 & 27 & 26,47 & 29 & 28,43 & 26 & 25,49 & 14 & 13,73 & 102 & 100 \\
\hline Razem & 15 & 5,02 & 63 & 21,07 & 147 & 49,16 & 58 & 19,40 & 16 & 5,35 & 299 & 100 \\
\hline
\end{tabular}

Źródło: badania własne.

Uzyskane przez badaną młodzież wyniki w zakresie samooceny nie są najlepsze, gdyż co czwarty badany uczeń posiada niewłaściwą, negatywną samoocenę. Wynik ten otrzymano przez zsumowanie wyników odnoszących się do bardzo niskiej i niskiej samooceny (5,02\% i 21,07\%) wszystkich badanych uczniów. Prawie 
połowę spośród badanych uczniów ze wszystkich typów szkół $(49,16 \%)$ cechuje przeciętny poziom samooceny, natomiast wysokie wyniki w zakresie samooceny osiągnął prawie co czwarty badany $(24,75 \%$, w tym $19,40 \%$ to wyniki wysokie i 5,35\% to wyniki bardzo wysokie). Taka sytuacja wydaje się dość korzystna, jednak uwzględniając analizę wyników badań w odniesieniu do uczniów z danej szkoły, obraz ten ulega dość znacznej zmianie. W przypadku uczniów technikum wśród badanych nie było osób posiadających bardzo wysoki poziom samooceny, a aż 7,14\% badanych $\mathrm{z}$ tej grupy uzyskało wyniki bardzo niskie. W przypadku uczniów z zasadniczej szkoły zawodowej tylko 2,02\% spośród nich miało bardzo niską samoocenę, taki sam wynik w tej grupie dotyczył uczniów o bardzo wysokiej samoocenie. Analizując przeciętne wyniki w zakresie poziomu samooceny, można zauważyć, że najliczniejszą grupę o takim poziomie samooceny stanowią właśnie uczniowie z zasadniczej szkoły zawodowej (61,62\% badanych z tej grupy). Nieco inaczej wygląda sytuacja wśród uczniów liceum, gdyż w tej grupie osoby o przeciętnym poziomie samooceny stanowią $28,43 \%$ wszystkich badanych uczniów $\mathrm{z}$ liceum, co czwarty badany $\mathrm{z}$ tej grupy posiada wysoki poziom samooceny $(25,49 \%)$ i aż $13,73 \%$ badanych licealistów przejawia bardzo wysoki poziom samooceny. Biorąc pod uwagę wszystkich badanych, można stwierdzić, że bardzo wysoki poziom samooceny występuje głównie wśród uczniów liceum. Wśród nich występują też osoby mające niską samoocenę, takie osoby to aż 32,35\% badanych $\mathrm{z}$ tej grupy. Wykres 2 ilustruje omawianą sytuację.

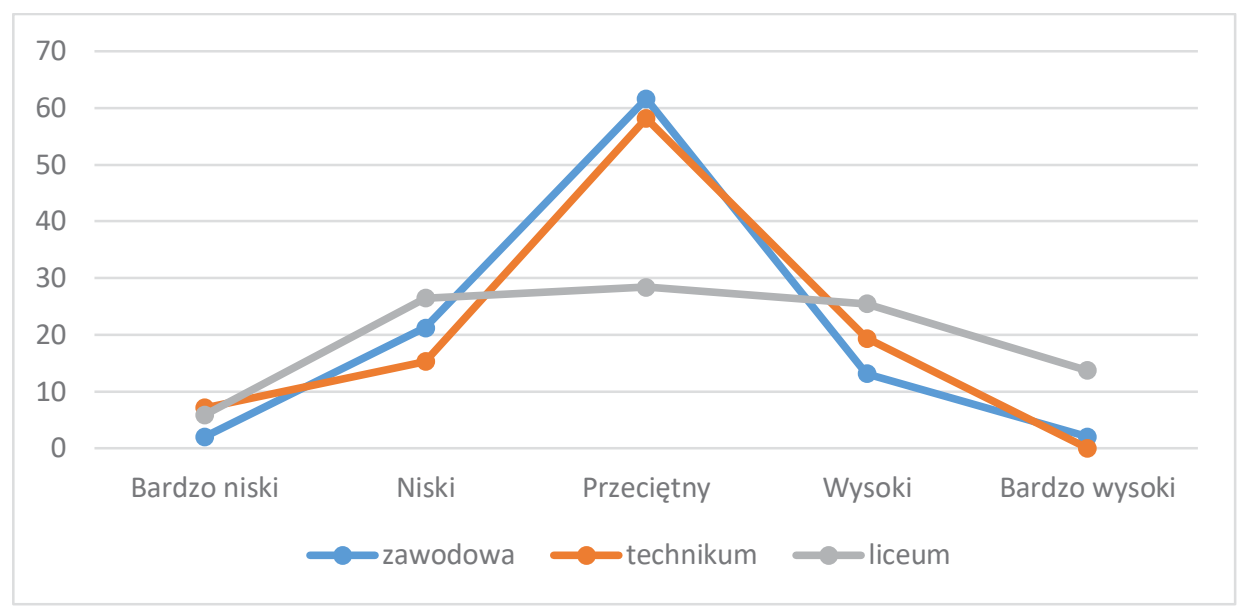

Wykres 2. Poziom samooceny uczniów z uwzględnieniem typu szkoły 
Biorąc pod uwagę typ szkoły, do której uczęszczają badani uczniowie, można stwierdzić, że uczniowie z zasadniczej szkoły zawodowej i technikum osiągnęli, pomimo pewnych różnic, podobne wyniki w zakresie poszczególnych poziomów samooceny, o czym świadczą linie wykresów dla obu grup. Rozkład poszczególnych wyników w obu porównywanych grupach był zbliżony do rozkładu normalnego (krzywej Gaussa), w którym największa liczba badanych uzyskała średni wynik w zakresie analizowanej zmiennej, a im dalej od wyniku średniego, tym mniej jest przypadków zarówno w odniesieniu do wyniku wysokiego, jak i niskiego. Natomiast w przypadku wyników uzyskanych w zakresie poziomu samooceny przez licealistów można stwierdzić dość równomierny ich rozkład, gdyż wyniki niskie uzyskało 32,35\% badanych licealistów (w tym 5,88\% to wyniki bardzo niskie i $26,47 \%$ niskie), przeciętne $28,43 \%$, a wysokie $39,22 \%$ (w tym $25,49 \%$ to wyniki wysokie i $13,73 \%$ bardzo wysokie). W tej grupie badanych można zatem zauważyć nieco inny kształt krzywej dzwonowej niż w pozostałych grupach.

W kontekście podjętego tematu interesujące wydało się poznanie, czy istnieją różnice w zakresie samooceny ze względu na płeć badanych osób. Otrzymane wyniki badań zaprezentowano w tabeli 3 .

Tabela 3. Samoocena badanych uczniów z uwzględnieniem płci badanych

\begin{tabular}{|l|c|c|c|c|}
\hline \multirow{2}{*}{ Płeć } & \multicolumn{4}{|c|}{ Samoocena } \\
\cline { 2 - 3 } & $\bar{\chi}$ & $\hat{\boldsymbol{S}}$ & $\boldsymbol{t}$ & $\boldsymbol{p}$ \\
\hline Kobiety & 28,49 & 4,80 & & \\
\hline Mężczyźni & 29,14 & 4,62 & \multirow{2}{*}{1,27} & 0,20 \\
\hline Razem & 28,76 & 4,72 & & \\
\hline
\end{tabular}

Źródło: badania własne.

Uzyskane wyniki badań dotyczące samooceny badanych kobiet i mężczyzn wskazują na brak różnic istotnych statystycznie pomiędzy porównywanymi grupami $(t=1,27 ; p=0,20)$. Po uwzględnieniu wieku i płci badanych osób uzyskany średni wynik zarówno przez badane kobiety $(28,49)$, jak i mężczyzn $(29,14)$ w skali stenowej plasuje się na poziomie 5 stena, co wskazuje na przeciętny poziom ich samooceny.

W tej sytuacji ciekawe wydało się bardziej szczegółowe poznanie poziomu badanej zmiennej wśród kobiet i mężczyzn. Tabela 4 ukazuje poziom samooceny badanych uczniów z uwzględnieniem ich płci. 
Tabela 4. Poziom samooceny badanych uczniów z uwzględnieniem płci

\begin{tabular}{|c|c|c|c|c|c|c|c|c|c|c|c|c|}
\hline \multirow{3}{*}{ Płeć } & \multicolumn{10}{|c|}{ Samoocena } & \multirow{2}{*}{\multicolumn{2}{|c|}{ Razem }} \\
\hline & \multicolumn{2}{|c|}{ Bardzo niski } & \multicolumn{2}{|c|}{ Niski } & \multicolumn{2}{|c|}{ Przeciętny } & \multicolumn{2}{|c|}{ Wysoki } & \multicolumn{2}{|c|}{$\begin{array}{l}\text { Bardzo } \\
\text { wysoki }\end{array}$} & & \\
\hline & $N$ & $\%$ & $N$ & $\%$ & $N$ & $\%$ & $N$ & $\%$ & $N$ & $\%$ & $N$ & $\%$ \\
\hline Kobiety & 7 & 4,64 & 34 & 22,52 & 63 & 41,72 & 36 & 23,84 & 11 & 7,28 & 151 & 100 \\
\hline Mężczyźni & 8 & 5,41 & 29 & 19,59 & 84 & 56,76 & 22 & 14,86 & 5 & 3,38 & 148 & 100 \\
\hline Razem & 15 & 5,02 & 63 & 21,07 & 147 & 49,16 & 58 & 19,40 & 16 & 5,35 & 299 & 100 \\
\hline
\end{tabular}

Źródło: badania własne.

Analizując wyniki badań dotyczące poziomu samooceny badanych kobiet i mężczyzn, można zauważyć, że rozkład wyników w porównywanych grupach jest podobny. Jednak można stwierdzić, iż wyniki uzyskane przez kobiety w zakresie wysokiego i bardzo wysokiego poziomu samooceny są korzystniejsze niż te uzyskane przez mężczyzn. Warto także zwrócić uwagę, że w grupie mężczyzn aż 56,76\% badanych osiągnęło przeciętny poziom samooceny, natomiast w grupie kobiet wskaźnik ten wyniósł 41,72\%. Omawiane wyniki badań w zakresie samooceny badanych kobiet i mężczyzn ilustruje wykres 3 .

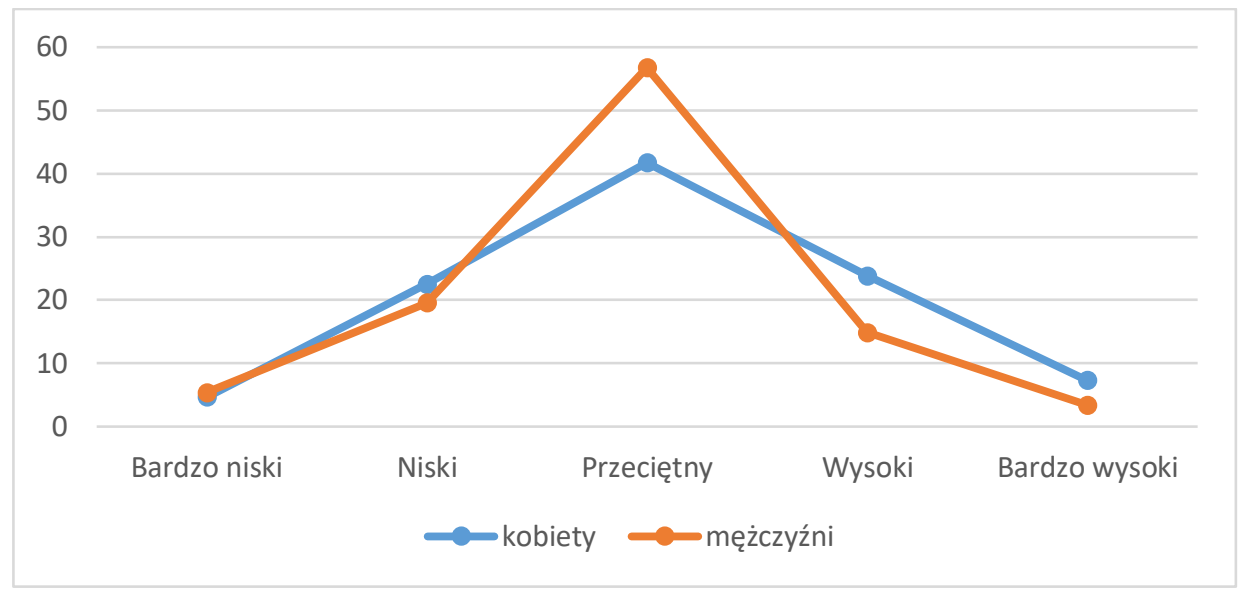

Wykres 3. Poziom samooceny badanych uczniów z uwzględnieniem płci

Sytuacja ukazana na wykresie wskazuje, że zarówno w grupie badanych kobiet, jak i mężczyzn przeważają osoby o przeciętnym poziomie samooceny. Uzyskane wyniki w zakresie bardzo niskiej i niskiej samooceny w obu grupach są bardzo zbliżone, natomiast wśród osób $\mathrm{z}$ wysokim i bardzo wysokim poziomem samooceny więcej jest kobiet niż mężczyzn. 


\section{PODSUMOWANIE}

Na podstawie przeprowadzonych badań można stwierdzić, że większość badanej młodzieży stojącej u progu dalszego kształcenia lub tranzycji na rynek pracy przejawia przeciętny poziom samooceny. Podobne wyniki uzyskano w badaniach prowadzonych wśród młodzieży w wieku 16-19 lat przez Henryka Kulasa w 1976 roku; nieco odmienne w badaniach prowadzonych przez Agnieszkę Buczak i Małgorzatę Samujło w 2013 roku wśród młodzieży w wieku 19-22 lata, gdyż najliczniejszą grupę w badaniach autorek stanowiły osoby z niską samooceną. Należy jednak wziąć pod uwagę, że pomiar samooceny w przytoczonych badaniach został dokonany przy użyciu innych narzędzi diagnostycznych, stąd mogą wynikać różnice w uzyskanych wynikach.

Porównanie średnich wyników w zakresie samooceny uzyskanych przez uczniów zasadniczej szkoły zawodowej, technikum i liceum ogólnokształcącego wskazało, że istniejące różnice między porównywanymi grupami są nieistotne ze względów statystycznych. Biorąc pod uwagę płeć badanych osób, uzyskane wyniki odnośnie do samooceny kobiet i mężczyzn nie różnicowały tych grup w sposób istotny statystycznie.

Badania wykazały jednak, że wśród badanych jest dość znaczna grupa osób o niskiej (21,07\% ogółu badanych) i bardzo niskiej (5,02\%) samoocenie. Warto $\mathrm{w}$ tym miejscu odwołać się do badań Baumeister i in. (2003), na podstawie których stwierdzono, że osoby $\mathrm{z}$ wysoką samooceną $\mathrm{w}$ porównaniu $\mathrm{z}$ osobami z niską samooceną postrzegają siebie korzystniej, przejawiają większą inicjatywę w osiąganiu celów, są bardziej wytrwałe, częściej podejmują wyzwania i ryzyko z nimi związane, łatwiej radzą sobie z sytuacjami trudnymi i stresem, nie mają trudności w relacjach z ludźmi. Osoby zaś z niską samooceną częściej są ostrożne, starają się unikać porażek, są niepewne siebie.

Należałoby zatem podjąć kroki w kierunku pracy nad poprawą przekonania na temat własnej wartości, szczególnie wśród tych młodych osób, które posiadają negatywną postawę wobec własnego Ja, co z pewnością będzie miało wpływ na ich decyzje edukacyjne i zawodowe, a w konsekwencji będzie odnosić się także do jakości życia. Korzystniejsze postrzeganie siebie pozwoli młodym ludziom uwierzyć w swoje możliwości i podjąć wyzwania, które są w stanie zrealizować.

Dla wielu młodych ludzi szkoła to jedyne takie miejsce, w którym przy właściwej pracy wychowawczej pedagogów mają szansę na korektę swojej samooceny, w przypadku uczniów kończących naukę na tym etapie edukacyjnym niejednokrotnie jest to już ostatnia szansa, by w sposób świadomy, celowy i profesjonalny wzmocnić samoocenę tych, którzy tego najbardziej potrzebują. Zdaniem Bogusława Śliwerskiego (2001) szkoła powinna stanowić poszerzenie dotychczasowej przestrzeni życia dziecka dla jego indywidualnego oraz społecznego rozwoju. Powinna być dla 
ucznia miejscem systematycznego zdobywania, poszerzenia i zgłębiania wiedzy zarówno o otaczającym go świecie, jak i o sobie samym, po to, by przygotować młodego człowieka do odpowiedzialnego i samodzielnego życia po zakończeniu edukacji. Jednak w wielu szkołach postulaty te często zostają jedynie deklaracją, a funkcja wychowawcza szkoły - teorią nieznajdującą miejsca w praktyce, gdyż zamiast wzmacniać, rozwijać samoocenę uczniów, raczej pozbawia się ich pewności siebie, krytykuje i karze (Wosik-Kawala 2007, s. 11).

Należy mieć jednak świadomość, że za taki stan nie można winić tylko nauczycieli, gdyż pierwszym środowiskiem odpowiedzialnym za właściwe wychowanie dzieci i młodzieży jest rodzina. Jednak wielu rodziców przenosi obowiązek wychowania dziecka na szkołę, którą obarczają winą za złe zachowanie, słabe oceny, brak umiejętności współżycia koleżeńskiego oraz niekorzystne postrzeganie siebie przez ucznia (Wosik-Kawala 2013, s. 9-10).

Ze względu na niewielką liczebnie próbę badawczą otrzymane wyniki i płynące z nich wnioski należy traktować dość ostrożnie. Być może badania te przyczynią się do podjęcia dalszych eksploracji badawczych w tym kierunku.

\section{LITERATURA}

Aronson E., Wilson T.D., Akert R.M., 1997, Psychologia społeczna. Serce i umyst. W: W. Domachowski (red.), tłum. A. Bezwińska i in., Poznań, Wydawnictwo Zysk i S-ka.

Baumeister R.F., Campbell J.D., Krueger J.I., Vohs K.D., 2003, Does high self-esteem cause better performance, interpersonal success, happiness, or healthier lifestyles? „Psychological Science in the Public Interest”, nr 4(1), 1-44.

Brzezińska A., 1973, Struktura obrazu własnej osoby i jego wplyw na zachowanie. „Kwartalnik Pedagogiczny”, nr 3, 87-97.

Brzezińska A., 2003, Portrety psychologiczne człowieka. Jak zmienia się człowiek w ciagu życia? „Remedium”, nr 4(122), 1-3.

Buczak A., Samujło M., 2013, Samoocena globalna i postrzeganie własnego ciała a zachowania żywieniowe studentów. „Lubelski Rocznik Pedagogiczny”, t. 32, 232-242.

Czerwińska-Jasiewicz M., 1997, Decyzje młodzieży dotyczace własnej przyszłości (uwarunkowania psychospołeczne). Warszawa, Oficyna Wydawnicza WP UW.

Dzwonkowska I., Lachowicz-Tabaczek K., Laguna M., 2008, Samoocena i jej pomiar SES. Polska adaptacja skali SES M. Rosenberga. Podręcznik. Warszawa, Pracownia Testów Psychologicznych.

Grabowiec A., 2011, Samoocena dzieci krzywdzonych w rodzinie. Lublin, Wydawnictwo UMCS. 
Kirenko J., 2002, Wsparcie społeczne osób z niepełnosprawnością. Ryki, Wyższa Szkoła Umiejętności Pedagogicznych i Zarządzania.

Kulas H., 1986, Samoocena młodzieży. Warszawa, Wydawnictwa Szkolne i Pedagogiczne.

Kulig M., 1988, Samoocena - jej rodzaje i rola $w$ funkcjonowaniu ucznia $w$ zespole rówieśników. „Życie Szkoły”, nr 7-8, 418-423.

Musiał D., 2007, Kształtowanie się tożsamości w adolescencji. „Studia z Psychologii w KUL”, t. 14, 73-92.

Niebrzydowski L., 1974, Zależność planów i dążeń życiowych uczniów klas V-VIII od posiadanej samooceny. „Psychologia Wychowawcza”, nr 3, 359-366.

Niebrzydowski L., 1976, O poznawaniu i ocenie samego siebie. Warszawa, Nasza Księgarnia.

Niebrzydowski L., 1989, Psychologia wychowawcza. Samoświadomość, aktywność, stosunki interpersonalne. Warszawa, PWN.

Obuchowska I., 1983, Psychologia rozwojowa dla rodziców. Okres dorastania. Warszawa, Nasza Księgarnia.

Obuchowska I., 1996, Drogi dorastania. Psychologia rozwojowa okresu dorastania dla rodziców i wychowawców. Warszawa, Wydawnictwa Szkolne i Pedagogiczne.

Obuchowska I., 2010, Adolescencja. W: B. Harwas-Napierała, J. Trempała (red.), Psychologia rozwoju człowieka, wyd. 3-6 dodruk, Warszawa, PWN, 163-201.

Podolska-Filipowicz E., 2004, Profesjonalne i nieprofesjonalne doradztwo zawodowe. W: H. Bednarczyk, J. Figurski, M. Żurek (red.), Pedagogika pracy. Doradztwo zawodowe. Warszawa-Radom, WSP ZNP - Wydawnictwo ITE.

Przetacznik-Gierowska M., Tyszkowa M., 2009, Psychologia rozwoju człowieka, t. 1. Warszawa, Wydawnictwo Naukowe PWN.

Reykowski J., 1982, Osobowość jako centralny system regulacji i integracji czynności człowieka. W: T. Tomaszewski (red.), Psychologia. Warszawa, PWN, 762-825.

Śliwerski B., 2001, Program wychowawczy szkoły. Warszawa, WSiP.

Tyszkowa M., 1972, Problemy psychicznej odporności dzieci i młodzieży. Warszawa, Nasza Księgarnia.

Wojciszke B., 2015, Psychologia społeczna. Warszawa, Wydawnictwo Naukowe Scholar.

Wosik-Kawala D., 2007, Korygowanie samooceny uczniów gimnazjum. Lublin, Wydawnictwo UMCS.

Wosik-Kawala D., 2013, Rozwijanie kompetencji emocjonalnych uczniów szkót ponadgimnazjalnych. Lublin, Wydawnictwo UMCS.

Wosik-Kawala D., Sarzyńska-Mazurek E., 2017, Wartość pracy w percepcji młodzieży stojącej u progu kariery zawodowej. Lublin, Wydawnictwo UMCS.

Wosińska W., 2004, Psychologia życia społecznego. Gdańsk, Gdańskie Wydawnictwo Psychologiczne. 


\title{
SELF-ESTEEM OF YOUTH STANDING AT THE THRESHOLD \\ OF FURTHER EDUCATION OR TRANSITION TO THE LABOUR MARKET - \\ ON THE EXAMPLE OF STUDENTS OF LUBLIN SECONDARY SCHOOLS
}

\begin{abstract}
Self-esteem is one of the factors conditioning the functioning of people in many areas of life, both personal and professional. It influences decisions made by people, including their professional career. The aim of the carried out research was an attempt to determine the self-esteem of young people at the threshold of further education or transition to the labour market. 299 students of Lublin schools, including: basic vocational school, technical secondary school and general high school, made a research sample. The Rosenberg Self-Esteem Scale (SES) by Morris Rosenberg was used in the research. Analysis of the data showed that students from various types of schools, standing at the threshold of adulthood do not differ significantly in terms of their self-esteem. Differences were also not noted, taking into account the gender of the people examined. However, the fact that as many as every fourth respondent had a low, unfavourable level of self-esteem turned out to be disturbing. In the case of these students, action should be taken to increase their self-esteem.
\end{abstract}

Keywords: adolescence, self-esteem, students, young people 